УДК [719:72](571.13-25)

DOI: 10.32340/2414-9101-2021-2-30-35

Ю. Р. Горелова, кандидат исторических наук, доцент

Сибирский филиал Института культурного и природного наследия им. Д. С. Лихачёва, Сибирский государственный автомобильно-дорожный университет (Омск, Россия) gorelovaj@mail.ru

\title{
ФОРМЫ СОХРАНЕНИЯ АРХИТЕКТУРНОГО НАСЛЕДИЯ В ИСТОРИЧЕСКОЙ ЗАСТРОЙКЕ КРУПНЫХ ГОРОДОВ СИБИРИ (НА МАТЕРИАЛАХ ОМСКА)
}

Аннотация. Охарактеризованы типовые варианты ведения консервационно-реставрационных работ на объектах архитектурного наследия, расположенных в городах юга Западной Сибири (на примере г. Омска Омской области, Россия): с сохранением исходного практического назначения архитектурных сооружений или изменением их функциональной роли. Изложен авторский взгляд на современные задачи воссоздания и сохранения подлинного облика провинциальных архитектурных комплексов (включая памятники религиозного значения), представляющих культурно-историческую и семиотическую ценность.

Ключевые слова: сибирский город, Западная Сибирь, Омск, городская архитектура, памятник архитектуры, архитектурное наследие, реставрачия, реновация, актуализация архитектурного наследия.

Архитектурная среда современного города уплотнена и пресыщена практически до предела, что, несомненно, актуализирует проблему сохранения и использования объектов историко-архитектурного наследия. Постоянное уплотнение застройки в центральной части города приводит как к нарушению целостности исторической среды, так и к утрате отдельных весьма ценных памятников. При этом даже сегодня можно найти достаточно целостные участки исторической застройки, культурная уникальность которых еще не пострадала от внедрения объектов, не согласующихся с основной массой по масштабности, цветовому решению, материалам и другим параметрам. Такие участки среды представляют собой фрагменты культурного ландшафта предыдущих эпох.

Необходимо понимать, что на сегодняшнем этапе простая консервация объектов наследия является методом крайне расточительным и по сути невозможным. Любое здание должно жить, функционировать и приносить пользу «здесь и сейчас», должно быть наполнено какой-то общественно-полезной функцией. В связи с этим, с одной стороны, необходимо создавать предпосылки для формирования гармоничной городской среды, отвечающей новым требованиям современной жизни, с другой - сохранять культурно-исторические традиции прошлого.

Одним из методов сохранения памятников архитектуры является формирование так называемых музеев архитектуры под открытым небом. Такой формат предоставляет возможность воссоздания атмосферы культурного ландшафта определенной эпохи. В России во второй половине прошлого столетия активизировалась работа по созданию музеев под открытым небом. Необходимо отметить, что не всегда опыт становился удачным. При перенесении объектов из одного контекста в другой, нередко нарушалась целостность визуального кадра, терялась историческая выразительность. Другой распространенной проблемой становился тот факт, что собранные вместе памятники архитектуры не гармонировали друг с другом, что опять же сводило всю работу по воссозданию целостных кусочков ландшафта к нулю. Еще одна проблема заключалась в потере аутентичности построек. Зачастую переносимые здания собирались с применением новых технологий, взамен утраченных приемов народных мастеров. 
Из регионального опыта можно вспомнить создание в 1971 году на территории Академгородка в городе Новосибирске Музея Института археологии и этнографии, основными экспонатами которого стали Спасо-Преображенская клетская церковь с колокольней из Зашиверского острога, Северная и Южная башни малой сторожевой крепости Юильского (Кызымского) острога с реки Кызым Ханты-Мансийского национального округа и др. В Иркутске в бывшем доме купца Шастина, после реставрации разместился «Дом Европы», приспособленный для проведения различных культурных мероприятий.

В Омской области в качестве примера можно упомянуть Омский государственный историко-культурный музей-заповедник «Старина Сибирская», расположенный в районном центре Большеречье в 200 км от Омска. Формирование архитектурно-этнографического комплекса «Старина Сибирская» началось в непростые 1990-е гг. с реставрации дома купца Н. Я. Гладкова. К моменту начала ремонтно-реставрационных работ памятник находился в плачевном состоянии, многие элементы резного декора были утрачены, их пришлось воссоздавать по старым фотографиям, которые сохранились в музее. Вместе с домом Гладкова музей получил обширную прилегающую территорию, на которой было решено устроить архитектурно-этнографический музей под открытым небом. В деревне Мало-Каиркуль Шипицынского сельского поселения сохранилось две избы братьев Дроздовых, датируемые второй половиной XIX в. Срубы разобрали и перевезли на территорию музея. Из двух изб сложили одну. Так началось формирование комплекса. Впоследствии из с. Такмык перевезли амбар и дом потомственных ямщиков Копьевых, в котором, следуя в Илимскую ссылку, останавливался писатель А. Н. Радищев, отреставрировали дом другого П. Я. Гладкова. Впоследствии к музею отошло еще несколько исторических зданий, в частности, дом купца Василия Ивановича Рещикова. В большинстве из них разместились экспозиции. Кроме того, при музее была открыта лавка по продаже изделий народных промыслов, чайная, берестяная мастерская. В части помещений разместилась администрация музея. На территории комплекса. По образцу 99-летней церкви Святого Александра Невского (с. Екатериновка Тевризского района) на территории музея воссоздали часовню во имя святого благоверного князя Александра Невского, впоследствии еще появилась колокольня.

На территории самого города Омска можно отметить существование культурно-исторического комплекса «Омская крепость», включившего в себя такие отреставрированные объекты Второй Омской крепости, как Денежная кладовая (1798), Воскресенский собор (1769), Тобольские ворота (1791-1793), Иртышские ворота (1768), Инженерная мастерская (1843), Цейхгауз артиллерийский (1832), Арсенал (1845) и др.

Здание кладовой решено в стилистике старорусских палат и имеет секционную планировку и окна с коваными решетками. При реставрации здания были использованы чертежи, хранящиеся в Российском военно-историческом архиве. Воскресенский собор был главным храмом крепости. В планировочном отношении Воскресенский собор относился к храмам зального типа, в стилистическом - соответствовал эстетике провинциального барокко. Двухсветный храм с арочными окнами первоначально венчался башенкой с куполом. По поводу ворот следует добавить, что в крепость вели четверо ворот, однако сохранились только Тобольские. Тарские были разрушены в 1957-1958 гг. (к настоящему времени воссозданы на прежнем месте), Омские и Иртышские (разобраны в 1930-е гг.) также воссозданы заново и располагаются на территории комплекса Омской крепости. Здание инженерных мастерских помнит Ф. М. Достоевского. Именно в этом здании в 1850 году на него были одеты, а в 1854 сняты кандалы. $\mathrm{B}$ середине XX века здесь находилось пожарное депо, из-за чего проемы дверей изменили свои изначальные очертания. После реставрации в здании организован выставочный зал и кинозал историко-культурного комплекса. По поводу цейхгауза стоит добавить, что еще в дореволюционный период (1873 г.) с южной стороны к нему была пристроена церковь, а в советский период там располагалась столовая военной части. Сегодня здание используется для нужд историкокультурного комплекса. Строительство Арсенала началось с возведения помещений кузницы, которые представляли собой несколько комнат и к которым впоследствии, и было пристроено здание Арсенала. По назначению он использовался не долго, очень скоро превратился 
в оружейную мастерскую. В 1910 году здание было передано Стрелковому полку. В советский период в нем располагались склады. Историко-культурное значение этого комплекса для Омска трудно переоценить. В проводимых нами неоднократно опросах общественного мнения, горожане называли комплекс Омской крепости одной из ярких визитных карточек города [1].

На данный момент в Омске этот комплекс является первой попыткой если не реставрации в полном смысле, то частичного воссоздания облика фрагмента исторической застройки. Притом, что существуют и другие фрагменты среды, в рамках которых достаточно высок процент сохранности уникальной исторической застройки (например, некоторые участки ул. Красных Зорь в бывшем Казачьем форштадте). Любинский проспект также может рассматриваться как целостный фрагмент культурного ландшафта, занимающего для Омска особо значимое в семиотическом отношении положение. По данным вышеупомянутых нами опросов, именно Любинский проспект занимает лидирующее положение и воспринимается самым значимым в семиотическом отношении пространством для Омска. Не случайно, проект строительства на улице Бударина (в непосредственной близости Любинского проспекта) высотного здания, способного нарушить целостность архитектурного ландшафта улицы, вызвал протесты не только со стороны активистов омского отделения ВООПИК, но и взволновал широкие массы городской общественности, в результате чего строительство высотки было приостановлено.

В Омске, применительно к отдельным объектам можно говорить о реализации нескольких методов сохранения архитектурно-исторического наследия. Первый из них - реставрация с сохранением исторической функции. Примером могут служить здания магазинов на Любинском проспекте. Хотя в большинстве случаев в процессе реставрации здания потеряли часть своего неповторимого облика за счет перепланировки внутренних помещений, изменения внешнего облика оконных проемов, некорректного цветового решения фасадов и других визуальных нюансов.

В 1998 г. проходила реставрация дома купцов Волковых, в котором уже долгое время располагается офис компании «Оша». В 1999 г. производственно-строительная организация «Омскгражданстрой» приступила к масштабной реставрации здания Кадетского корпуса.

Второй метод - реставрация с заменой исторического функционала здания. Яркий пример - здание бывшего Торгового корпуса, в котором долгое время размещался корпус Сибирского государственного автомобильно-дорожного института (ныне университет), а сегодня располагается один из корпусов Омского областного музея изобразительных искусств им. М. А. Врубеля. Здание корпуса было построено по проекту томского архитектора А. Д. Крячкова в стиле эклектики с преобладанием стилизации под московский ампир. На первом этаже разместились разнообразные магазины, на втором - городской общественный банк, нотариус и другие городские учреждения. В подвале торговали фруктами. Интересно, что другой корпус музея им. М. А. Врубеля располагается также в одном из красивейших исторических зданий Омска - генерал-губернаторском дворце. Строительство дворца началось в 1859 г. по проекту Ф. Ф. Вагнера и под руководством инженера К. Е. Лазарева и было закончено в 1862 г. Перед дворцом и позади него были разбиты два сада. Дворец был построен по образцу русских городских усадеб в стиле русского зрелого классицизма. В комплекс дворца входили одноэтажные надворные постройки, конюшни, жилые помещения для прислуги и служебные помещения. Центральная часть здания акцентирована поэтажным ордером, углы замкнуты рустованными лопатками, здание имеет бельведер с полуциркульными окнами. Последним генерал-губернатором, занимавшим этот дворец, был Н. А. Сухомлинов. В марте 1917 г. в здании разместился Совет рабочих и солдатских депутатов и Коалиционный комитет, представлявший Временное правительство в Омске. Дворец стал называться Домом республики. После мятежа белочехов в июне 1918 г., когда в здании расположился эсеро-меньшевистский комиссариат, Дом республики был переименован в Дом свободы. Вскоре комиссариат сменился Временным Сибирским правительством, а еще позднее - правительством адмирала А. В. Колчака. После прихода в город отрядов Красной армии, М. Н. Тухаческий поместил свой штаб именно в этом здании. В апреле 1923 г. здание было передано Западно-Сибирскому краевому музею и с этого времени не меняло своей функциональной направленности. 
В данном случае можно вспомнить и музей им. Ф. М. Достоевского на территории Второй Омской крепости, расположившийся в бывшем комендантском доме 1799 года постройки. В 1799-1864 гг. в доме жили коменданты крепости (эта должность была учреждена Указом сибирского губернатора 7 июля 1765 г.). Последним комендантом был А. Ф. де Граве (1793-1864), вступивший в должность в 1841 г. В октябре 1864 г. Омская крепость и комендантское правление были упразднены. В бывшем комендантском доме были размещены офицерские квартиры. В стилистическом отношении данное здание является переходным от барокко к классицизму и потому сочетает черты обоих стилей. Архитектурно-художественный облик этого одноэтажного здания определяют пилястры, членящие фасад на три части. Центральная часть фасада акцентирована высоким фронтоном.

Примером изменения функции может послужить и история с реконструкцией кинотеатра «Художественный» (бывший «Кристал-Палас») под органный зал и др. В 2002-2003 гг. проходила реставрация здания бывшего управления Омской железной дороги, в котором сейчас находится Омский государственный университет путей сообщения.

Иногда, в процессе реставрации, здание, наоборот, восстанавливало утраченный ранее функционал. Так в 1997-1998 гг. по проекту Омскгражданпроекта реставрировалось бывшее здание Омской городской думы, в котором долгие годы располагалась областная библиотека им. А. С. Пушкина, а ныне опять размещается орган городского управления - Омский городской Совет.

Третий метод, активно применявшийся в Омске последние тридцать лет - реновация, возведение аналогов разрушенных зданий из новых материалов, по новым технологиям, но с сохранением основных визуальных черт (по старым историческим фотографиям) и преимущественно на исторических местах. Яркими примерами тут могут служить уже упоминавшиеся нами ворота второй Омской крепости, Серафимо-Алексеевская часовня, часовня Иверской Божьей матери, Успенский кафедральный собор.

Часовня Иверской Богоматери и Святого и Преподобного Сергия Радонежского Чудотворца была выстроена в 1867 г. на средства купца Федора Курганского. Она замыкала восточную сторону Любинского проспекта. Была разрушена в советский период, воссоздана в 1996 г. Другая часовня, Серафимо-Алексеевская - замыкала западную сторону Любинского проспекта. Построена была Серафимо-Алексеевская часовня в 1907 г. В начале 1920-х гг. часовня перестала быть действующей. В 1927 г. по решению президиума Омского горсовета ее снесли. В начале 1980-х гг. художником В. А. Десятовым был разработан проект восстановления часовни по старым фотографиям. Закладка состоялась в мае 1992 г., а освящение - в декабре 1994 г.

Успенский кафедральный собор был заложен в 1891 г. и освящен в 1898 г. Храм являлся образчиком русского стиля и подражал русской храмовой архитектуре XVII в. Собор был пятиглавым с мощным центральным куполом и шатровой колокольней, имел луковичные позолоченные купола, обилие полуциркулярных окон, прорезавших барабаны куполов и верхнего яруса колокольни, стилизованные под древнерусский стиль детали фасадов, окрашенных в белый цвет, с вставками из красного кирпича. Храм являлся одной из главных архитектурных доминант дореволюционного Омска и находился на пересечении главных городских улиц. После революции, в 1933 г. с храма были сняты купола, в 1935 г. храм был взорван.

В сентябре 2005 года на заседании Попечительского совета по воссозданию Успенского кафедрального собора была представлена концепция воссоздания этого памятника истории и культуры, которая была одобрена и утверждена Градостроительным советом (22 сентября 2005 г.). 13 января 2006 года в выставочном зале Дома художника состоялось открытие выставки «Успенский собор: вчера, сегодня, завтра». На выставке представлены работы омских фотографов В. Кудринского, В. Буйницкого, картины известных омских художников С. Патрахина, Г. Кичигина, Е. Смирновой, Е. Сочивко, П. Минина, А. Чермошенцева, а также материалы раскопок, предоставленные фондом охраны археологического наследия и НПО «Мостовик». Помимо этого, была предоставлена возможность ознакомиться с эскизными предложениями по восстановлению 
фасадов Успенского кафедрального собора. 15 июля 2007 г. состоялась торжественная церемония открытия Успенского Кафедрального собора. Затем состоялась церемония освящения храма и Божественная литургия.

Еще одним из вариантов реконструкции исторических зданий является расширение площади помещений путем пристраивания дополнительных объемов. Примером удачной реконструкции такого типа может служить здание областной прокуратуры в центре города на ул. Ленина (памятник архитектурной эклектики XIX в.), получившее пристройку (проект архитектора О. В. Колесниковой). Еще одним примером пристройки дополнительного объема (в данном случае мансардного этажа) является здание бывшей гостиницы «Сибирь» (1940 г. постройки). Масштабный гостиничный комплекс на ул. Пушкина стал пристройкой к памятнику архитектуры начала XX в. - особняку в стиле модерн.

Удачной можно признать осуществленную в 2006 г. реконструкцию здания железнодорожного вокзала. Новосибирским архитекторам института «Сибжелдорпроект» удалось сохранить исторический облик здания. При этом здание вокзала получило дополнительный верхний этаж.

Таким образом, можно констатировать, что в настоящее время общество осознает ценность объектов наследия и их важной роли в сохранении культурной преемственности, что выражается в разнообразии способов и вариантов его сохранения и использования [1, с. 168]. Наследие всегда должно включать именно те ценности, которые необходимы обществу для поддержания культурной идентичности и для передачи последующим поколениям. При этом критерий актуализации и признания данных объектов в качестве ценных, следует считать обязательным. Разделяя данное заключение, современные исследователи А. А. Правоторова и В. Л. Гусаченко подчеркивают, что объекты наследия обязательно должны удовлетв орять трем основным критериям. Во-первых, они должны быть в зоне внимания современного общества (критерий актуализации). Во-вторых, они должны быть доступны для восприятия. Для удовлетворения первых двух условий, третьим должно стать необходимость обеспечения сохранности [2, с. 5-11].

В заключении необходимо еще раз подчеркнуть, что в современной ситуации, сохранение объектов наследия нерасторжимо связано с проблемой его актуализации и наполнения новыми, актуальными для современности общественными функциями. При этом, конечно же, приоритетным должно признаваться использование зданий, представляющих историческую и художественную ценность под функции образования, просвещения, культуры и искусства, что позволит максимально полно использовать их потенциал как объектов, способных формировать позитивную культурную идентичность и содействовать воспроизведению базовых культурных ценностей общества.

\section{Список литературы}

1. Горелова, Ю. Р. Городская среда в восприятии жителей крупного провинциального города (на материалах г. Омска) // Урбанистика. - 2017. - № 1. - C. 51-60. - DOI: 10.7256/23108673.2017.1.21203176 (дата обращения: 10.02.2021).

2. Горелова, Ю. Р. Историко-культурный потенциал территории - фактор обеспечения культурной преемственности и формирования позитивного образа территории // Культурология в Сибири: научные центры, направления исследований, социокультурные тренды : сб. науч. ст., посвящ. 25-летию Сиб. филиала Ин-та наследия. - Москва : Ин-т наследия, 2018. С. $157-168$.

3. Правоторова, А. А. Гусаченко В.Л. Город и наследие / А. А. Праворотова, В. Л. Гусаченко. - Новосибирск : НПЦ по сохранению ист.-культ. наследия Новосиб. обл., 2002. $252 \mathrm{c}$. 
Iulia R. Gorelova, Ph. D. in History, Associate Professor Siberian Branch of Likhachev Russian Research Institute for Cultural and Natural Heritage, Siberian State Automolibe and Highway University (Omsk, Russia) gorelovaj@mail.ru

\title{
WAYS OF PRESERVATION OF ARCHITECTURAL HERITAGE IN HISTORIC DEVELOPMENT OF BIG SIBERIAN CITIES (A CASE OF OMSK)
}

\begin{abstract}
The paper describes typical versions of conservation and restoration work operated on architectural monuments located in cities of the South of West Siberia (using the example of Omsk, Omsk Oblast, Russia); on the one hand, such efforts can drive at preservation of original function of an architectural constructions, on the other hand, it can lead to shift in its role. The author outlines her own view on the current tasks of renovation and preservation of true figure of provincial architectural complexes (including religion monuments) that have cultural, historical and semiotical value.

Keywords: a Siberian city, West Siberia, Omsk, urban architecture, a monument of architecture, architectural heritage, restoration, renovation, popularization of architectural heritage.
\end{abstract}

УДК 2:[159.923.2:17.021.3]

DOI: $10.32340 / 2414-9101-2021-2-35-44$

М. М. Мурат, доктор религиоведения, профессор Институт образования и инноваций г. Гдыня (г. Гдыня, Польша) drmurat65@gmail.com

\section{РЕЛИГИЯ - «КРАЕУГОЛЬНЫЙ КАМЕНЬ» СОЦИАЛЬНОЙ ИДЕНТИЧНОСТИ ${ }^{1}$}

\begin{abstract}
Аннотация. Автор аргументирует тезис, согласно которому общность религиозных убеждений - ключевой фактор социальной самоидентификации и объединения социальных групп, населяющих государство. Религиозное знание позволяет упорядочить многомерное противоречивое смысловое пространство, разделяя его на сферы сакрального и профанного. Религиозное знание облегчает поиск экзистенциального пути в пространстве сверхсложных взаимосвязей происходящего, лабиринте культурных кодов и артефактов. Охарактеризован социально-интегративный потенциал монотеистических религий (иудаизма, христианства, ислама) в контексте становления и развития имперской государственности. Автор приходит к выводу, что, несмотря на наличие статистических данных, свидетельствующих о снижении роли религии в жизни различных социально-демографических категорий, она продолжает оставаться важной силой, формирующей коллективное самосознание сообществ.
\end{abstract}

Ключевые слова: религия, идентичность, монотеизм, сакральное, профанное, сочиальное пространство, культурный артефакт, коммуникативные коды, христианство, иудаизм, ислам.

\section{1.Религия как форма общественного сознания}

Религия как форма духовной культуры не исчерпывается только мировоззренческим и догматическим значением, представляет собой социальное явление. Религия институциализирована

\footnotetext{
${ }^{1}$ Перевод с польского Е. Н. Халецкой.
} 